\title{
EVALUATION OF SCIENTIFIC PRODUCTION IN MEXICAN STATE PUBLIC UNIVERSITIES (2007-2011) USING PRINCIPAL COMPONENT ANALYSIS
}

\author{
Evaluación de la producción científica en \\ universidades públicas estatales mexicanas (2007- \\ 2011) usando análisis de componentes principales
}

Javier Tarango, Perla-Zukey Hernández-Gutiérrez and David Vázquez-Guzmán

Nota: Este artículo puede leerse traducido al español en

http://www.elprofesionaldelainformacion.com/contenidos/2015/sep/06_esp.pdf

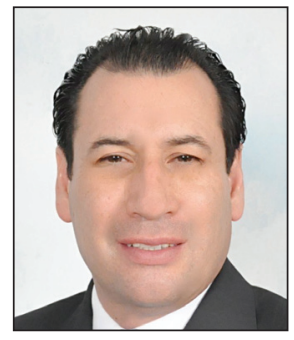

Javier Tarango, full-time professor-researcher in the Autonomous University of Chihuahua (UACH), is a member of the National Researchers System (level I). He is a doctor in education (UACH), master in information sciences (Guanajuato University) and master in organizational development (Monterrey University). Lines of research: Evaluation of scientific production and informational literacy. He has published four books, 20 book chapters, 32 scientific articles, and 24 congress proceedings; and he has supervised 27 thesis dissertations.

http://orcid.org/0000-0002-0416-3400

Universidad Autónoma de Chihuahua, Facultad de Filosofía y Letras José de Gálvez, 6707. Rincones de San Francisco, 31115 Chihuahua, Chih., México tj.88888@hotmail.com

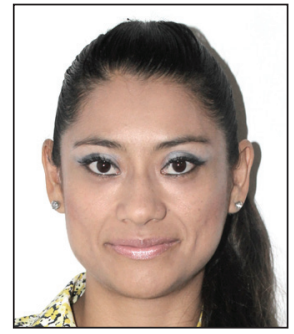

Perla-Zukey Hernández-Gutiérrez, doctoral student in education (Autonomous University of Chihuahua, $U A C H)$, master of sports sciences with an option in biology (UACH). Professor in the School of Physical Culture Sciences, UACH. She is the author of two articles in scientific journals. http://orcid.org/0000-0002-0364-7016

Universidad Autónoma de Chihuahua, Facultad de Ciencias de la Cultura Física Paseo de la Sierra, 15322. Paseos de Chihuahua, 31125 Chihuahua, Chih., México zukeyhg@hotmail.com

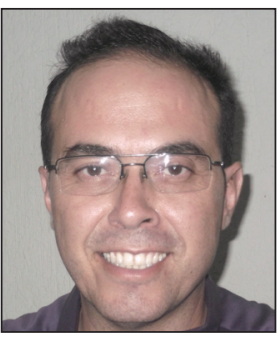

David Vázquez-Guzmán is a member of the National Researchers System (level I). Full-time professor of the Autonomous University of Ciudad Juarez, Department of Social Sciences. He has a $\mathrm{PhD}$ from the University of Stirling, UK, a masters in economics (University of California, Riverside) and a masters in administration (Monterrey Institute of Technology). Lines of research: Aspects of development economics and microeconomics in relation to welfare and vulnerable populations. He has published four books and 10 scientific journal articles.

http://orcid.org/0000-0001-8254-9766

Universidad Autónoma de Ciudad Juárez, Departamento de Ciencias Sociales Av. Colegio Militar y Universidad, Zona Chamizal, 32300 Ciudad Juárez, Chih., México david.vazquez@uacj.mx

\begin{abstract}
This article focuses on the application of the principal component analysis (PCA) method to evaluate the competitiveness of scientific production in Mexican universities, based on the identification and classification of a set of indicators, grouped into seven dimensions and 18 criteria. Specifically, the method was performed in the educational institutions included in the category of state public universities (33 in total), over a period of five years (2007-2011), and ultimately identified only seven
\end{abstract}


criteria as principal components, resulting in a scale of positions that indicate the index of relative potential (IPR in Spanish). Thus, the levels of opportunity for each university in relation to their group are defined, and the university that showed the highest competitiveness is identified and it in turn becomes a quality parameter.

\section{Keywords}

Scientific production; Principal component analysis (PCA); Institutional competitiveness; Index of relative potential; State public universities; Mexico.

\section{Resumen}

Se aplica el método de análisis de componentes principales (ACP) para evaluar la competitividad en producción científica de universidades mexicanas, partiendo de la identificación y clasificación de un conjunto de indicadores, agrupados en 7 dimensiones y 18 criterios. De forma específica, el método se llevó a cabo en las entidades educativas incluidas dentro del rubro de universidades públicas estatales (33 en total), en un período de cinco años (2007-2011). Con ello se determina, que por su comportamiento significativo, sólo se identifican 7 criterios como componentes principales, dando como resultado una escala de posiciones que indican el índice de potencialidad relativa (IPR), definiéndose así los niveles de oportunidad de cada entidad participante en relación con su grupo, además de reconocer a la institución que mostró mayor competitividad y que se convierte a su vez, en un parámetro de calidad.

\section{Palabras clave}

Producción científica; Análisis de componentes principales (ACP); Competitividad institucional; Índice de potencialidad relativa; Universidades públicas estatales; México.

Tarango, Javier; Hernández-Gutiérrez, Perla-Zukey; Vázquez-Guzmán, David (2015). "Evaluation of scientific production in Mexican state public universities (2007-2011) using principal component analysis". El profesional de la información, v. 24, n. 5, pp. 567-576
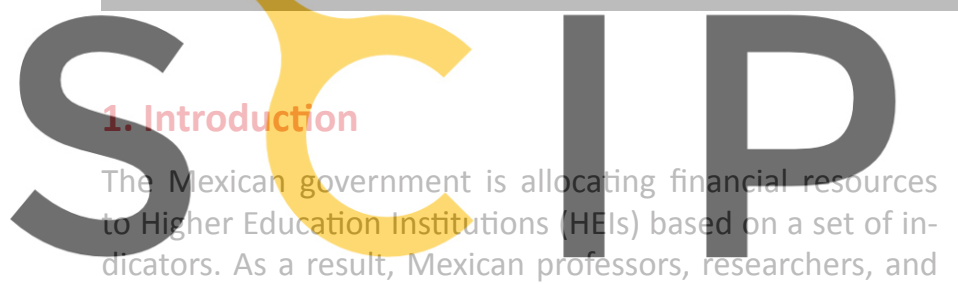

higher education institutions (HEIs) are under mounting

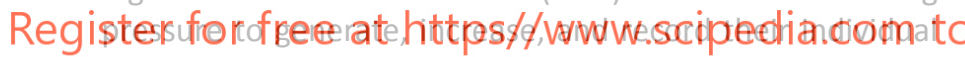
and collective academic and scientific production. However, there is no clear method for tracking, measuring, and evaluating this output.

Though the definitions of scientific production in Mexican universities are vague, it is easy to identify the products, actions, and environments that are of greater value, which is necessary if researchers want to maintain an individual and institutional status of quality. In order of relevance, the government guidelines for instructors and researchers are integrated into four action axes: generation and communication of knowledge, teaching, student tutoring (formation of human resources through thesis dissertation development, especially in graduate studies), and institutional management.

Although these fields of action can be disaggregated to the most specific level, it is the first level that determines the individual scientific production capacity, which is based on non-specific guidelines and is identified through two measurement approaches: the first related to the amount of products generated (especially scientific articles); and the second, related to quality, measured through visibility and impact indexes. Though the conceptualization of scientific production is defined as a process by which scientists interact creating new knowledge, and whose results are disse-

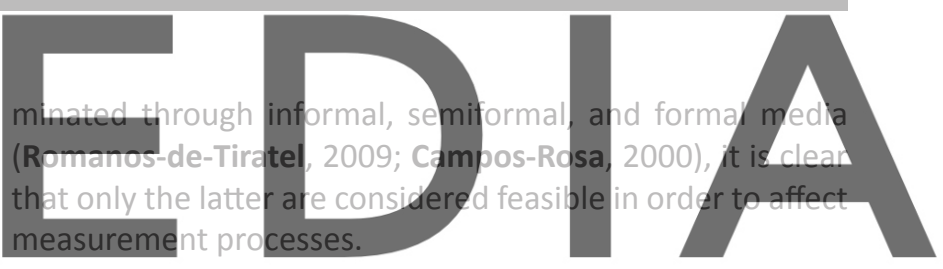

Academic and scientific communities are well aware of the dow des scientific articles, thesis dissertations, books, and book chapters (Braga-Ferreira; Malerbo; Silva, 2003); they also know that in order to make science it is necessary to write it down and publish it (Campos-Rosa, 2000); and competitiveness in educational institutions is created whenever their scientific research processes are constant and systematic (Shults, 2005).

The great majority of academics in Mexican universities were hired for teaching; however, current demands in higher education lean towards strengthening the research profile, and as a result it is necessary for faculty to develop knowledge generation processes as their jobs become more multidimensional (Gorbea-Portal, 2010). Such trends show that the Mexican university system needs to respond timely to world challenges, steering strategies towards the identification of scientific production potentialities for the development of intellectual and social capital (Modrego, 2002).

The measurement of scientific competitiveness requires the recording of behaviors through time and not as isolated facts (Bonzi, 1992), including also the consideration of the teacher's academic status in relation to his type of work relation, gender, work field, citation patterns, and above all the need of pondering the academic and research environments that are characteristic of HEls. Mexican universities 
really need to define their order of priorities, since in the observation of Manjarin; Cutri; Torres; Noguerol; Ossorio; Durán; Ferrero (2009), it is common for Mexican academics to participate frequently in easier activities (such as lectures in congresses) and not in apparently complex substantial actions, such as publishing academic articles, which has become a priority in the government's measurements.

\section{Research objectives}

This study presents the following objectives:

a) To define and classify the evaluation dimensions and criteria for scientific production in Mexican universities.

b) To demonstrate the applicability of the PCA model in the identification of institutional competitiveness in scientific production, using the results observed in Mexican state public universities.

c) To identify institutional rankings according to scientific production by using the IPR; results will help guide decision making for the development of the evaluated educational organizations.

The definition of scientific production is often vague, though it is easy to identify which products, actions, and environ-

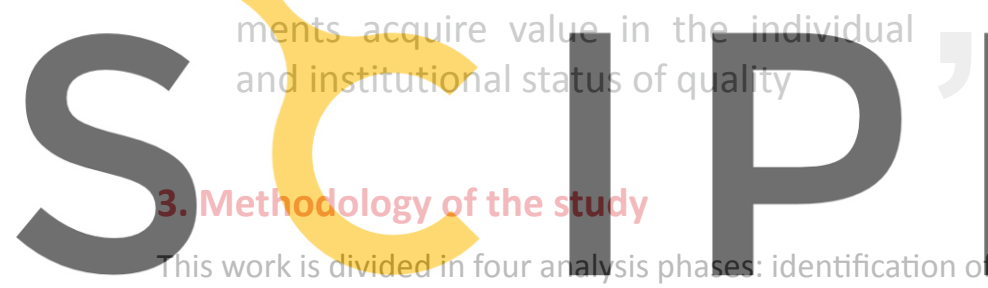

data starting from Access to scientific observatories; crea-

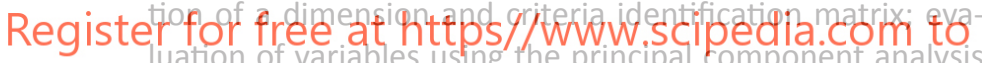

(PCA) as a central model; and creation of the IPR to compare institutional positions. The analyzed resuits cover every contribution to scientific production of the evaluated universities out of the total of scholars in the institution, regularly with the following denominations: professors (instructors), professors-researchers, and researchers, which have a fulltime, part-time, and hourly-rate work relation.

\subsection{Identification of data in scientific observatory}

As the source of information for data collection we identified the scientific observatory developed by Mexico's $\mathrm{Na}$ tional Autonomous University (UNAM, 2011, 2012) called Comparative Study of Mexican Universities (ECUM in Spanish), a project that systematizes, measures, and compares the performance of Mexican universities and other highereducation institutions (approx. 2,800 entities), in which the information can be segmented into different categories (in this case by type of university).

Data collection corresponded to the period 2007-2011 (five years), because these years were available at the time of the study. Though the scientific observatory allows for multiple ways of displaying data, for this study they were sorted into two alternative combinations: by type of university (federal public institutions, state public institutions, private institu- tions, federal technological institutes, state technological institutes, technological universities, polytechnic universities, intercultural universities, and other public universities) and multiannual selection (the years that correspond to the evaluation period).

Since it is a descriptive study, the data collected from the observatory were designed over the possibility of establishing a relevant type and level of comparison, for that we obtained unweighted data without indicators of behavior comparisons, in a way that the study, starting from the application of the PCA model, would establish relations in the study's criteria and construct indicators from the model's own needs and perspectives of analysis.

\subsection{Creation of a dimension and criteria matrix}

Once the general data collection was carried out and according to their disposition, we identified 18 evaluation criteria that are related to scientific production and two more that complemented the information: number of students, and instructors. Such criteria were grouped according to their affinity in six dimensions related to scientific production, and one more group that integrated the complementary data mentioned before (see Attachment).

\subsection{Application of the PCA model for data analysis}

For the data analysis and the definition of the level of com.

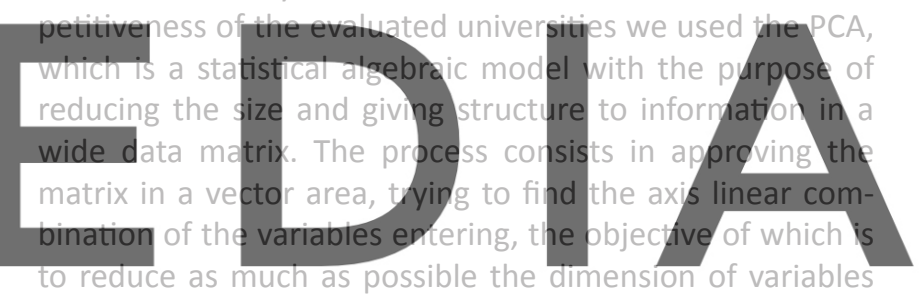

entered or original variables (Lozares-Colina; López-Roldán,

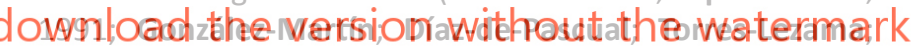

Garnica-Olmos,1994), in a way that when it is possible to identify smaller variables that have a differentiated behavior (similarities and differences) out of a group of interrelated variables called principal variables, these are considered for the analysis.

The new variables (principal components) are weighted obtaining a decreasing order of relevance according to their variance percentage, thus the PCA allowed for the identification of the causes for variability of a set of data, and sorting them by relevance, using descriptive statistical multivariable techniques, which variables were measured on each of the subjects (universities) obtaining data matrices (Terrádez-Gurrea, 2012; Pla, 1986).

The analysis compared the behavior of the variables and in a dual form, in the area of the subjects (universities), to later plot such results in a graph, in a way that both in the table as in the graphical representation the data with the greater original variability ration are observed (Manly, 2004).

\subsection{Identification of the IPR}

The incorporation of this concept by the authors refers to the comparison of the scientific production levels of a set of entities, identifying the best results (represented in positive numbers) and the least favorable results (represented in ne- 
gative numbers), as well as those with a closer approximation to the arithmetical mean, through the proximity to zero out of the total of the studied group.

The IPR means that the best results are representative of the subject group, however they are considered relative since they do not mean there is a sufficient level of competitiveness with different or wider environments. However, it identifies positions of particular entities in relation to their necessities for growth in scientific production, whether to get closer to the group's arithmetical mean or to be comparable to those who obtained the best indicators.

\subsection{Delimitation of the study}

Given the coincidence of localized data according to the evaluated criteria and their performance level in scientific production, the researchers applied the PCA to state public universities because:

a) They are the most renresentative of higher education in Mexico, both in numbers and in geographical distribution (33 public universities located in 31 out of the 33 states).

b) They are educational entities that create, define the plans, and permanence of their academic programs; promote their academic personnel; and usually enroll a varied and great number of students.

c) They are characterized for participating in the totality of the dimensions and criteria that integrate the catalog that we tollow in this research work.

4. Analysis of results
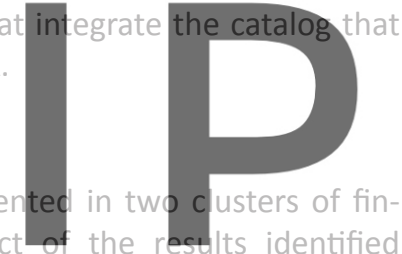

alysis of results is presented in two c usters of fin-
The first is the product of the results identified

through the ECUM observatory when studying the overview

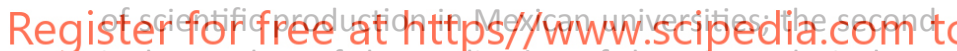
is the product of the application of the PCA exclusively to state public universities.

\subsection{Overview of scientific production in Mexican uni- versities}

Though the study is limited to the application of the PCA model to Mexican state public universities, it was considered pertinent to present succinctly the general behavior of the approximately 2,400 entities in the ECUM, segmented in the nine groups mentioned above.

It should be noted that in each group we observe different characteristic nuances, from their historical context, atten- ding population, the structure of their academic models, the definition of strategic objectives, and the role of the instructors within their work environments. The analysis of these variables warrants a more in-depth study, justified by the complexity we can observe in the Mexican higher educational system (Mendoza-Rojas, 2009).

Specifically, from a historical perspective, in the Mexican educational system there are universities founded in the times of the Viceroyalty of New Spain (such as UNAM), as well as educational options that arose in recent decades, represented by technological, polytechnical, and intercultural universities, each with different purposes that do not necessarily prioritize scientific production as part of their activities (Romero-Muñoz, 2008).

The great majority of teachers in universities were hired to teach, but in recent times, the profile of the researcher has acquired more relevance

First we start from the fact that the distribution by type of educational institution according to their frequency is concentrated in private schools ( $81.87 \%$ of the total), whereas $21.93 \%$ are public institutions, with the lower frequency

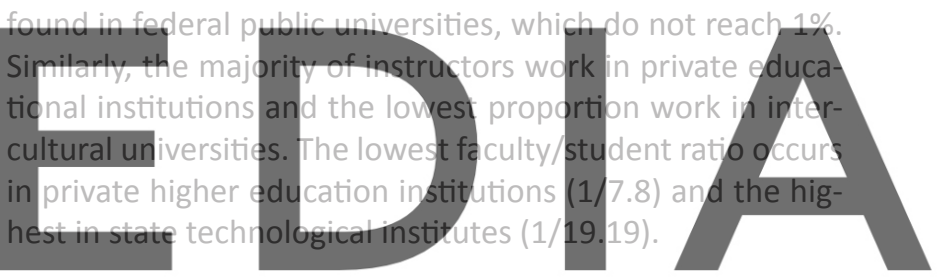

The academic, economic, and social resources and activities, specifically thpse related to research, may not depend on download the versign Whithout the Watermark

that historical issues and strategic purposes may have more influence on the distribution and development of faculty activities. However, other quantitative indicators should be taken into account which may influence behavior in scientific production, for example, evaluating the time in which an instructor is also a researcher (Bernáldez-Aguilar, 2005).

The following data relates to scientific production (20072011) by type of university:

a) The two types of universities that offer representative and systematic results are federal public universities and state public universities. In the case of federal public technologi-

Table 1. Variables (criteria) identified as principal components

\begin{tabular}{|l|l|}
\hline \multicolumn{1}{|c|}{ Dimension } & Criteria \\
\hline Knowledge generation processes & Publication of indexed articles \\
\hline Academic quality of the scholars & Enabling scholars towards educational quality \\
\hline Characterization of the scientific production impact & Regional and institutional collaboration levels \\
\hline Innovation capacity & Number of patents filed \\
\hline Environments for the professional exercise & Capacity for collegiate work (academic bodies in consolidation process) \\
\hline Institutional capacity for scientific publication management & Scientific journals in Conacyt's catalogue \\
\hline General data & Number of students \\
\hline
\end{tabular}


Table 2. Yearly results of positions of competitiveness in scientific production, 2007-2011

\begin{tabular}{|c|c|c|c|c|c|c|c|c|}
\hline State universities & $\begin{array}{l}\text { Publication } \\
\text { of indexed } \\
\text { articles }\end{array}$ & $\begin{array}{c}\text { Enabling } \\
\text { scholars } \\
\text { towards } \\
\text { educational } \\
\text { quality }\end{array}$ & $\begin{array}{c}\text { Regional and } \\
\text { institutional } \\
\text { collaboration } \\
\text { levels }\end{array}$ & $\begin{array}{c}\text { Number } \\
\text { of } \\
\text { patents } \\
\text { filed }\end{array}$ & $\begin{array}{c}\text { Capacity for } \\
\text { collegiate work } \\
\text { (academic bodies } \\
\text { in consolidation } \\
\text { process) }\end{array}$ & $\begin{array}{l}\text { Scientific } \\
\text { journals in } \\
\text { Conacyt's } \\
\text { catalogue }\end{array}$ & $\begin{array}{c}\text { Number } \\
\text { of } \\
\text { students }\end{array}$ & IPR \\
\hline & \multicolumn{8}{|c|}{2007} \\
\hline Univ. Aut. de Nuevo León & 177 & 158 & 201 & 6 & 36 & 0 & 66.400 & 2,232 \\
\hline Univ. de Guadalajara & 201 & 417 & 199 & 0 & 80 & 2 & 74.265 & 2,199 \\
\hline Univ. Aut. del Estado de Morelos & 165 & 82 & 181 & 0 & 26 & 0 & 11.470 & 1,902 \\
\hline Benemerita Univ. Aut. de Puebla & 170 & 162 & 176 & 0 & 67 & 2 & 44.545 & 1,820 \\
\hline Univ. Aut. de San Luis Potosí & 138 & 95 & 156 & 0 & 14 & 0 & 20.640 & 1,490 \\
\hline Univ. Aut. del Carmen & 7 & 26 & 14 & 0 & 2 & 0 & 3.983 & $-0,853$ \\
\hline Univ. Aut. de Guerrero & 11 & 191 & 14 & 0 & 16 & 0 & 21.717 & $-0,853$ \\
\hline Univ. Aut. de Chiapas & 7 & 71 & 12 & 0 & 5 & 0 & 18.486 & $-0,886$ \\
\hline Univ. De Quintana Roo & 7 & 22 & 8 & 0 & 4 & 0 & 3.179 & $-0,952$ \\
\hline \multirow[t]{2}{*}{ Univ. Aut. Benito Juárez de Oaxaca } & 3 & 21 & 4 & 0 & 4 & 0 & 18.885 & $-1,018$ \\
\hline & \multicolumn{8}{|c|}{2008} \\
\hline Univ. De Guadalajara & 285 & 416 & 271 & 0 & 80 & 2 & 77.316 & 2,771 \\
\hline Univ. Aut. de Nuevo León & 236 & 61 & 252 & 6 & 36 & 0 & 68.940 & 2,503 \\
\hline Univ. Aut. del Estado de México & 107 & 88 & 178 & 0 & 31 & 2 & 36.299 & 1,458 \\
\hline Univ. Aut. del Estado de Morelos & 163 & 34 & 174 & 0 & 26 & 0 & 11.414 & 1,401 \\
\hline Univ. Aut. de San Luis Potosí & 155 & 30 & 166 & 0 & 14 & 0 & 21.775 & 1,288 \\
\hline Univ. Aut. del Estado de Hidalgo & 98 & 40 & 16 & 0 & 11 & 0 & 19.714 & $-0,830$ \\
\hline Univ. Aut. de Nayarit & 17 & 5 & 15 & 0 & 5 & 0 & 11.895 & $-0,844$ \\
\hline Univ. de Quintana Roo & 10 & 4 & 12 & 0 & 4 & 0 & 3.260 & $-0,887$ \\
\hline Univ. Aut. del Carmen & 10 & 26 & 11 & 0 & 2 & 0 & 4.066 & $-0,901$ \\
\hline \multirow[t]{2}{*}{ Univ. Aut. Benito Juárez de Oaxaca } & 4 & 4 & 4 & 0 & 4 & 0 & 18.698 & $-1,000$ \\
\hline & \multicolumn{8}{|c|}{2009} \\
\hline Universidad de Guadalajara & 267 & 358 & 382 & 0 & 78 & 3 & 82.543 & 4,485 \\
\hline Benemerita Univ. Aut. de Puebla & 234 & 161 & 168 & 0 & 73 & 2 & 50.088 & 1,392 \\
\hline Univ. Aut. de Nuevo León & 260 & 155 & 354 & 7 & 37 & 0 & 71.650 & 1,298 \\
\hline U.yiv. Veracruzana & 114 & & 164 & 0 & 33 & 0 & 53.542 & \\
\hline Univ. Mich. de S. Nicolás de Hidalgo & 186 & & 232 & 0 & & 0 & 38.079 & \\
\hline Univ. Aut. de Baja California Sur & 12 & 26 & 35 & 0 & 6 & 0 & 4.805 & \\
\hline Univ. Aut. de Campeche & 35 & & 43 & 0 & 6 & 0 & & \\
\hline Univ. Aut. Benito Juárez de Oaxaca & 4 & 22 & 6 & 0 & 5 & 0 & 3.560 & $-0,78$ \\
\hline Univ. de Quintana Roo & 7 & 16 & 6 & 0 & 5 & 0 & 3.265 & $-0,884$ \\
\hline \multirow{2}{*}{ Univ. Aut. del Carmen } & 入 & 11 & 11 & 0 & 3 & 0 & 4.248 & $-0,962$ \\
\hline & \multicolumn{8}{|c|}{2010} \\
\hline
\end{tabular}

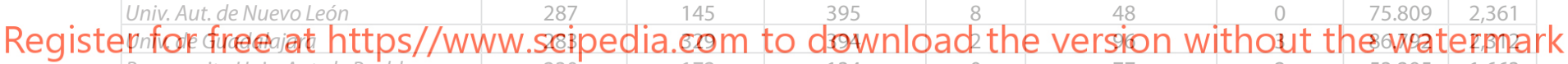
Benemerita Univ. Aut. de Puebla

\begin{tabular}{|c|c|c|c|c|c|c|c|c|}
\hline & & & & & & & & \\
\hline Univ. Aut. de San Luis Potosí & 213 & 66 & 283 & 0 & 25 & 0 & 23.468 & 1,455 \\
\hline Univ. Aut. del Estado de Morelos & 191 & 71 & 230 & 0 & 31 & 0 & 12.311 & 1,185 \\
\hline Univ. Aut. de Chiapas & 19 & 66 & 44 & 0 & S.D. & 0 & 20.550 & $-0,922$ \\
\hline Univ. Aut. de Ciudad Juárez & 19 & 54 & 45 & 0 & 23 & 0 & 21.116 & $-0,922$ \\
\hline Univ. Aut. Benito Juárez de Oaxaca & 13 & 20 & 16 & 0 & 4 & 0 & 16.949 & $-0,995$ \\
\hline Univ. de Quintana Roo & 12 & 16 & 12 & 0 & 6 & 0 & 3.432 & $-1,007$ \\
\hline \multirow[t]{2}{*}{ Universidad Aut. del Carmen } & 4 & 12 & 25 & 0 & 3 & 0 & 4.286 & $-1,105$ \\
\hline & \multicolumn{8}{|c|}{2011} \\
\hline Univ. de Guadalajara & 329 & 344 & 473 & 3 & 99 & 3 & 92.451 & 4,143 \\
\hline Benemerita Univ. Aut. de Puebla & 283 & 177 & 174 & 0 & 74 & 2 & 54.434 & 1,533 \\
\hline Univ. Veracruzana & 154 & 172 & 255 & 0 & 54 & 0 & 58.944 & 1,454 \\
\hline Univ. Aut. de Nuevo León & 326 & 159 & 439 & 9 & 55 & 0 & 79.246 & 1,251 \\
\hline Univ. Aut. del Estado de México & 189 & 134 & 386 & 0 & 36 & 2 & 41.362 & 0,860 \\
\hline Univ. Aut. de Campeche & 36 & 22 & 63 & 0 & 8 & 0 & 5.891 & $-0,891$ \\
\hline Univ. Aut. Benito Juárez de Oaxaca & 16 & 22 & 14 & 0 & 4 & 0 & 15.667 & $-0,891$ \\
\hline Univ. de Quintana Roo & 11 & 20 & 15 & 0 & 7 & 0 & 3.776 & $-0,922$ \\
\hline Univ. Aut. de Baja California Sur & 31 & 14 & 59 & 0 & 4 & 0 & 4.756 & $-1,016$ \\
\hline Univ. Aut. del Carmen & 20 & 13 & 29 & 0 & 4 & 0 & 4.511 & $-1,031$ \\
\hline
\end{tabular}

cal institutes and other public universities, their results are to a great degree not as representative, null, or sporadic in the six other types.

b) In relation to the publications with impact (indexing in the WoS), there is a dominance of federal public universities, with an average by institution of 517.4 articles with a longitudinal growth of $25.46 \%$, followed by state public uni- versities with an average of 84.4 articles by institution and a growth of $42 \%$. The included HEls located in other public universities only managed to publish an average of 5.2 articles by institution and federal public technological institutes only two articles by institution.

c) About the publication of peer-reviewed journals, the arithmetical means were: publications in Scopus, 675.8 ar- 
Table 3. General IPR positions, 2007-2011 average

\begin{tabular}{|c|c|c|c|c|c|c|c|c|c|}
\hline \multirow[b]{2}{*}{$\begin{array}{l}\text { Posi- } \\
\text { tion }\end{array}$} & \multirow[b]{2}{*}{ State universities } & \multicolumn{8}{|c|}{ 2007-2011 } \\
\hline & & $\begin{array}{l}\text { Publication } \\
\text { of indexed } \\
\text { articles }\end{array}$ & $\begin{array}{c}\text { Enabling } \\
\text { scholars } \\
\text { towards } \\
\text { educational } \\
\text { quality }\end{array}$ & $\begin{array}{c}\text { Regional and } \\
\text { institutional } \\
\text { collaboration } \\
\text { levels }\end{array}$ & $\begin{array}{c}\text { Number } \\
\text { of } \\
\text { patents } \\
\text { filed }\end{array}$ & $\begin{array}{c}\text { Capacity for } \\
\text { collegiate } \\
\text { work (acade- } \\
\text { mic bodies in } \\
\text { consolidation } \\
\text { process) } \\
\end{array}$ & $\begin{array}{l}\text { Scientific } \\
\text { journals in } \\
\text { Conacyt's } \\
\text { catalogue }\end{array}$ & $\begin{array}{c}\text { Number } \\
\text { of } \\
\text { students }\end{array}$ & IPR \\
\hline 1 & Univ. de Guadalajara & 273 & 369,8 & 343,8 & 1 & 86,6 & 2,6 & 82.674 & 3,182 \\
\hline 2 & Univ. Aut. de Nuevo León & 257,2 & 169 & 328,2 & 7,2 & 42,4 & 0 & 72.409 & 1,929 \\
\hline 3 & Benemerita Univ. Aut. de Puebla & 217,8 & 174,2 & 153,4 & 3 & 71,6 & 2 & 49.577 & 1,395 \\
\hline 4 & Univ. Mich. de S. Nicolás de Hidalgo & 172 & 128,4 & 195,6 & 0,4 & 36 & 0,4 & 37.545 & 0,898 \\
\hline 5 & Univ. Aut. del Estado de Morelos & 182,6 & 87 & 217,8 & 0 & 28,2 & 0 & 12.082 & 0,869 \\
\hline 6 & Univ. Aut. de San Luis Potosí & 182,6 & 92,6 & 229,8 & 0 & 18,4 & 0 & 22.454 & 0,792 \\
\hline 7 & Univ. de Guanajuato & 168,8 & 124 & 184,8 & 5 & 18,6 & 0 & 16.060 & 0,780 \\
\hline 8 & Univ. Veracruzana & 113,4 & 121 & 153,6 & 0 & 37,8 & 0 & 54.044 & 0,736 \\
\hline 9 & Univ. Aut. del Estado de Mexico & 129,6 & 118,8 & 234,4 & 0 & 35,2 & 2 & 37.520 & 0,723 \\
\hline 10 & Univ. Aut. de Baja California & 149,6 & 108,6 & 176,4 & 0 & 28,2 & 3,2 & 41.564 & 0,628 \\
\hline 11 & Univ. de Sonora & 117,2 & 69,8 & 141,8 & 0 & 23,8 & 0 & 23.892 & 0,228 \\
\hline 12 & Univ. Aut. de Yucatan & 106,8 & 80,6 & 147,4 & 3 & 25,2 & 1 & 12.465 & 0,146 \\
\hline 13 & Univ. de Colima & 77,2 & 67,2 & 89 & 0,8 & 19 & 0 & 11.700 & $-0,061$ \\
\hline 14 & Univ. Aut. de Sinaloa & 61,6 & 68,8 & 69,2 & 0 & 23,6 & 0 & 48.407 & $-0,210$ \\
\hline 15 & Univ. Aut. del Estado de Hidalgo & 104,2 & 61,2 & 41 & 0 & 15 & 0 & 20.073 & $-0,233$ \\
\hline 16 & Univ. Aut. de Zacatecas & 51,8 & 67 & 66,4 & 0 & 22,8 & 0 & 17.733 & $-0,234$ \\
\hline 17 & Univ. Aut. de Queretaro & 89,8 & 51,8 & 102 & 0 & 18,4 & 0 & 16.024 & $-0,253$ \\
\hline 18 & Univ. Aut de Guerrero & 32,6 & 110,8 & 36,4 & 0 & 18,2 & 0 & 22.984 & $-0,359$ \\
\hline 19 & Univ. Aut. de Tamaulipas & 49 & 40,8 & 67,8 & 1 & 14,2 & 0 & 39.826 & $-0,485$ \\
\hline 20 & Univ. Juárez Aut. de Tabasco & 34,2 & 50,6 & 46,8 & 1 & 17,6 & 1 & 26.498 & 401 \\
\hline & Univ. Aut. de Chihuahua & 34,6 & 62,4 & 45,6 & 0 & 15 & 0 & 23.662 & $-0,5$ \\
\hline & Univ. Aut. de Aguascalientes & 36,8 & 52,4 & 51 & 0 & 20,6 & 0 & 11.894 & $-6,522$ \\
\hline 23 & Univ. Aut. de Ciudad Juârez & 14,4 & 47,8 & 39,6 & 0 & 16,2 & 0 & 20.309 & $-0,525$ \\
\hline 24 & Univ. Aut. de Chiapas & 15,2 & 58,2 & 31 & 0 & 10,8 & 0 & 19.694 & $-0,580$ \\
\hline 25 & Univ. Aut. de Nayarit & 25,6 & 31,6 & 29,8 & 0 & 5,6 & 0 & 12.213 & $-0,638$ \\
\hline
\end{tabular}

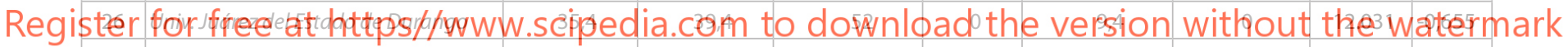

\begin{tabular}{|c|c|c|c|c|c|c|c|c|c|}
\hline 27 & Univ. Aut. de Tlaxcala & 24,2 & 32 & 30 & 0 & 9,4 & 0 & 10.337 & $-0,692$ \\
\hline 28 & Univ. Aut. de Coahuila & 27,8 & 48,4 & 40 & 1 & 38,1 & 0 & 22.496 & $-0,715$ \\
\hline 29 & Univ. Aut. de Campeche & 29,6 & 27 & 42,8 & 0 & 9,2 & 0 & 5.740 & $-0,733$ \\
\hline 30 & Univ. Aut. de Baja California Sur & 18,2 & 27,6 & 39,2 & 0 & 5,4 & 0 & 4.900 & $-0,798$ \\
\hline 31 & Univ. de Quintana Roo & 9,4 & 13,8 & 10,6 & 0 & 5,2 & 0 & 3.383 & $-0,930$ \\
\hline 32 & Univ. Aut. Benito Juarez de Oaxaca & 8 & 16,6 & 8,8 & 0 & 4,6 & 0 & 17.592 & $-0,939$ \\
\hline 33 & Univ. Aut. del Carmen & 9,6 & 19 & 18 & 0 & 2,8 & 0 & 4.218 & $-0,971$ \\
\hline
\end{tabular}

ticles (58.78\% growth) for federal public universities and 102.6 articles (53.19\% growth) for state public universities. A similar situation is found in the Clase and Periódica indexes.

d) The creation of their own means for scientific communication, by having scientific journals in the catalogs of Mexico's National Science and Technology Council (Conacyt in Spanish) and Latindex, only federal public universities show substantial indicators.

e) The recognition of scholars as national researchers again shows a higher concentration in federal public universities (an average of 661 members by institution, with a growth of $14.77 \%)$; state public universities have an institutional average of 129.4 , with a percentage growth of $33.97 \%$.
Although they are not representative enough, there is presence of federal public technological institutes and other public universities.

f) For graduate studies programs with recognition of quality (accredited by Mexico's National Quality Graduate Studies Program, or PNPC in Spanish), the leadership in participation is kept by federal public universities (an average of 37.2 accredited programs by institution, with a growth of $10 \%$ ), followed by state public universities with an institutional average of 15.2 programs with a growth of $35 \%$.

\subsection{Results of the PCA application in state public uni- versities.}

The information collected from state public universities, ac- 
cording to the dimensions and evaluation criteria matrix for scientific production, were analyzed using PCA (using the Stata statistical software), which allowed reducing a set of data, finding the causes for variability of only seven out of the total 18 criteria, which were identified as principal components (table 1). Each criterion showed a correspondence relation with one of the seven dimensions that compose the dimensions and criteria matrix.

Once the principal components were identified, the system itself created tables that compare the position of the evaluated universities according to their principal components, one by year in the period 2007-2011 and another table that averages the general results of the period mentioned before. In the case of the results obtained for each year, which summarized in table 2, titutions with the highest rons with the lowest indicators are shown, noting that sucl

The applicability of the principal component analysis in the evaluation of scientific production is determined by the identification of systematic and uniform data

Although every year there are important results of the positions of the evaluated universities per se, the obtained results weighing the 33 Mexican state public universities (table 3 ), identify the general average of the seven variables (criteria) during the evaluated period and the general position obtained in the IPR. A general interpretation allows the observation that the most competitive university in scientific production is Guadalajara's University with an IPR of 3.182 and the one with the lowest rank is the Del Carmen University (placed in position 33) with an IPR of -0.971 .

The IPR rank between the entity with the highest results and the one with the lowest results is an IPR of 4.153, while in order to reach the means of the evaluated group, it requires requires to increase their IPR in 3.036, which indicates that

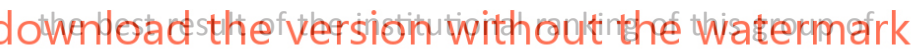
entities is way above the rest of the participating universities.

According to the position obtained in the IPR of the evaluated state public universities, represented in figure 1, we can observe the distribution of positions, identifying that 12 entities are placed above the average (36.36\%) and 21 below the average (63.63\%). We can also observe the low concentration of evaluated criteria with negative results, in addition of the growing rate experienced by universities with positive results (the number of the figure corresponds to the position obtained by each university in table 3 ).

The measurement of competitiveness in scientific production requires the record of the behavior of institutions through time and not as isolated events

The concentration of results provided by the PCA model, presented in figure 2, allowed for the observation of the variability of the IPR of each evaluated year, as well as the global results, enabling the identification of constancy levels 
in the scientific production development. Thus for instance, Mexican state public universities that observed the highest results showed a high variability in each evaluated year, while those with a the lowest results keep a permanent passive behavior, with a decreasing trend.

\section{Conclusions}

The results of this study allowed the demonstration of the PCA applicability (regularly used in economics and sociology) in the measurement of universities' scientific production competitiveness, both in short periods (one year) and in long periods (this time five years), with the advantage that it may be used with any kind of educational institution, regardless of the characteristics of the criteria included, whenever there are systematic data available (in the case of Mexico, it was only possible to apply to the PCA to two ty pes of universities: state public universities and federal public universities).

The PCA model offers the pos-

Regisiteryfardfreepatg bxteps/d/www.scipedia.com to download the version without the watermark

evaluation studies of scientific

production depending on the provision of data of later periods, it also facilitates comparisons of different groups of entities and their results which makes it easier to understand, verify, and correct institutional actions. Its main limitations are those related to the lack of availability of uniform information and that it should be considered that the shorter the evaluated period, the less compelling the results.

\section{References}

Bernáldez-Aguilar, María-José (2005). Autonomía y principios universitarios: Estudio jurídico para la defensa de la universidad pública de México (tesis licenciatura, Universidad Autónoma del Estado de México, 2005).

http://www.ordenjuridico.gob. $m x /$ Publicaciones/ Tesis2009/2LicDerPub.pdf

Braga-Ferreira, Cintia; Malerbo, Maria-Bernadete; Silva, Márcia-Regina (2003). "Errores en las referencias bibliográficas de la producción académica: un estudio de caso". Scire:
Representación y organización del conocimiento, v. 9, n. 1, enero-junio, pp. 133-138.

http://ibersid.eu/ojs/index.php/scire/article/view/1461

Bonzi, Susan (1992). "Trends in research productivity among senior faculty". Inf. process. \& management, v. 28, n. 1, pp. 111-120.

http://dx.doi.org/10.1016/0306-4573(92)90097-J

Campos-Rosa, Joaquín (2000). "La comunicación científica: ¿arte o ciencia?". Ars pharmaceutica, v. 41, n. 1, pp. 11-18. http://farmacia.ugr.es/ars/pdf/177.pdf

Gorbea-Portal, Salvador (coord.) (2010). Potencialidades de investigación y docencia iberoamericana en ciencias bibliote- 
cológicas y de la información. México, D.F.: Universidad Nacional Autónoma de México, Centro Universitario de Investigaciones Bibliotecológicas, 530 pp. ISBN: 9786070207518 http://132.248.242.6/ publica/conmutarl.php?arch=1\&idx=229

González-Martín, Pilar; Díaz-de-Pascual, Amelia; Torres-Lezama, Enrique; Garnica-Olmos, Elsy (1994). “Una aplicación del análisis de componentes principales en el área educativa". Revista de economía, v. 19, n. 9, pp. 55-72.

ftp://iies.faces.ula.ve/Pdf/Revista9/Rev9Gonzalez.pdf

Lozares-Colina, Carlos; López-Roldán, Pedro (1991). "El análisis de componentes principales: aplicación al análisis de datos secundarios". Papers. Revista de sociología, n. 37, pp. 31-63. http://www.raco.cat/index.php/Papers/article/download/25101/58447

Manjarin, Mercedes; Cutri, Adrián M.; Torres, Fernando A.; Noguerol, María E.; Ossorio, María F.; Durán, Pablo; Ferrero, Fernando (2009). "Evaluación de la producción científica en una residencia de pediatría". Archivos argentinos de pediatría, v. 107, n. 1, pp. 26-29.

http://www.scielo.org.ar/scielo.php?script=sci_arttext\&pid =S0325-00752009000100006

Manly, Bryan F. J. (2004). Multivariate statistical methods: A primer (3 ${ }^{\text {rd }}$ ed.). Boca Raton, Florida: CRC Press. ISBN: 978 1584884149

Mendoza-Rojas, Javier (2009). Financiamiento de la educación superior y crisis económica: Avances y limitacione cación superior y crisis econamica: Avances y limitacione educación superior. Uexico, educación superior. México, Universidades e Instituciones 86074510140

Modrego, Aurelia (coord.) (2002). Capital intelectual y pro ducción científica. Madrid, España: Comunidad de Madrid, Consejería de Educación, Dirección General de Investiga.

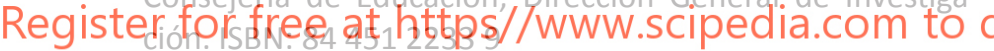
http://www.madrimasd.org/informacionidi/biblioteca/ publicacion/doc/Libro_12completo.pdf
Pla, Laura E. (1986). Análisis multivariado: Método de componentes principales. Washington, D.C.: Organización de Estados Americanos, Secretaría General, Instituto Interamericano de Estadística. ISBN: 0827024517

Romanos-de-Tiratel, Susana (2009). "Estrategias de difusión del conocimiento en ciencias del hombre: el caso de la Facultad de Filosofía y Letras de la Universidad de Buenos Aires, proyecto Ubacyt F157 (Programación científica 20082010)". Revista información, cultura y sociedad, n. 20, pp. 91-110.

http://www.scielo.org.ar/pdf/ics/n20/n20a06.pdf

Romero-Muñoz, José-Francisco (2008). Experiencias de vinculación universidad - sector productivo y social en la BUAP. México, D.F.: Anuies. ISBN: 9786074510003

Shults, Fred-Donald (2005). An empirical model for assessing academic research levels and capacities of colleges and universities (doctoral dissertation, University of Tennessee, Knoxville).

http://trace.tennessee.edu/utk_graddiss/2325

Terrádez-Gurrea, Manuel (2012). Análisis de componentes principales. Barcelona: Universitat Oberta de Catalunya (UOC).

http://www.uoc.edu/in3/emath/docs/Componentes_ principales.pdf

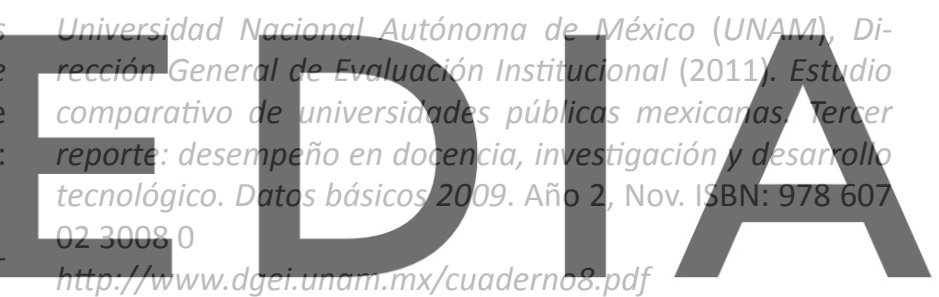

Universidad Nacional Autónoma de Méxjco (UNAM), Di-

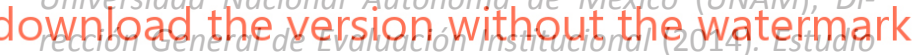

comparativo de universidades públicas mexicanas.

http://www.ecum.unam.mx

\section{Attachment: Dimensions and criteria matrix}

\begin{tabular}{|c|c|c|}
\hline Dimensions & Criteria & Definition \\
\hline \multirow{3}{*}{$\begin{array}{l}\text { Knowledge genera- } \\
\text { tion processes }\end{array}$} & $\begin{array}{l}\text { Publication of indexed } \\
\text { articles }\end{array}$ & $\begin{array}{l}\text { Counts articles registered in the Thomson-Reuters bibliographic indexs, that through the Web } \\
\text { of Science allow for the follow-up of scientific production. They identify indexes such as Impact } \\
\text { factor. }\end{array}$ \\
\hline & $\begin{array}{l}\text { Publication of peer- } \\
\text { reviewed articles }\end{array}$ & $\begin{array}{l}\text { They are articles registered in the Scopus bibliographic index. Applies the same methodological } \\
\text { procedures as the Thomson Reuters' WoS databases. }\end{array}$ \\
\hline & $\begin{array}{l}\text { Publication of dissemi- } \\
\text { nation articles }\end{array}$ & $\begin{array}{l}\text { They are articles registered in the bibliographic indexes of the databases Latin-American Cita- } \\
\text { tions in Social Sciences and Index of Latin-American Scientific Journals (Clase and Periódica respec- } \\
\text { tively in Spanish). Both are produced by the UNAM's Latin-American Bibliography Department } \\
\text { of the Sub-direction of Specialized Services of the General Direction of Libraries (DGB in Spanish). }\end{array}$ \\
\hline \multirow{3}{*}{$\begin{array}{l}\text { Educational quality of } \\
\text { scholars }\end{array}$} & $\begin{array}{l}\text { Enabling of scholars } \\
\text { with a preferential } \\
\text { degree }\end{array}$ & $\begin{array}{l}\text { It presents information about the total number of teaching personnel that attends the class- } \\
\text { room modality, according to their level of studies (the doctoral degree is preferential) and work- } \\
\text { ing time. Those who are only involved in research are excluded. }\end{array}$ \\
\hline & $\begin{array}{l}\text { Scholars with national } \\
\text { recognition (by level) }\end{array}$ & $\begin{array}{l}\text { Number of scholars that participate in the Researchers national system (SNI in Spanish), where it } \\
\text { is recognized the work of scholars dedicated to the production of scientific and technological } \\
\text { knowledge. }\end{array}$ \\
\hline & $\begin{array}{l}\text { Enabling of scholars } \\
\text { towards educational } \\
\text { quality }\end{array}$ & $\begin{array}{l}\text { Through the Program for Teachers' Professional Development (Prodep in Spanish) the relevant } \\
\text { participation of scholars is evaluated, with the purpose of identifying those who have improved } \\
\text { their professional profile. It applies only to full-time scholars. }\end{array}$ \\
\hline
\end{tabular}




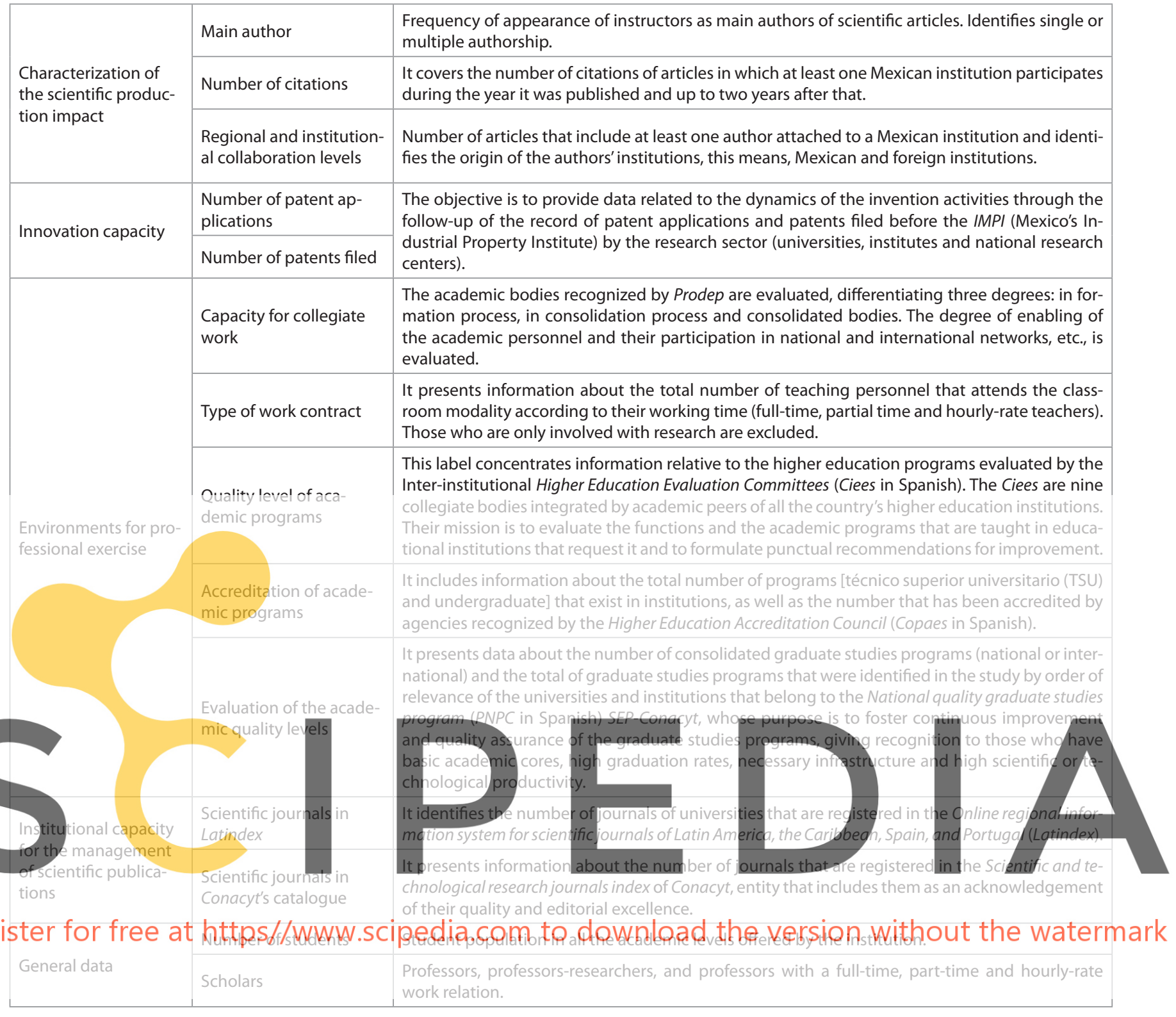

\section{RecBib

